\title{
DETERMINATION OF THE OPTIMAL CUTTING PARAMETERS FOR MACHINING TECHNICAL PLASTICS
}

\author{
DOLOČITEV OPTIMALNIH PARAMETROV REZANJA PRI \\ MEHANSKI OBDELAVI INDUSTRIJSKE PLASTIKE
}

\author{
Predrag Mošorinski $^{1}$, Slavica Prvulovic ${ }^{1 *}$, Ljubiša Josimovic ${ }^{2}$ \\ ${ }^{1}$ University of Novi Sad, Technical Faculty "Mihajlo Pupin", Department of mechanical engineering, Djure Djakovića bb, \\ 23000 Zrenjanin, Serbia \\ ${ }^{2}$ High Textile School, Vilema Pušmana 17, 16000 Leskovac, Serbia
}

Prejem rokopisa - received: 2019-04-11; sprejem za objavo - accepted for publication: 2019-09-18

doi:10.17222/mit.2019.079

\begin{abstract}
This paper analyses the process of improving the efficiency of a CNC lathe by performing experiments which involve the machining of plastics as well as programming of a fuzzy logic controller (FLC) for the required machining conditions to obtain the optimal factors of the cutting regime. The programming involved three characteristic input values and one output value while the experimental results involved generating the main cutting force and the temperature in the cutting zone during the machining on the CNC lathe. The expected results of the adapted FLC are based on the complete autonomy of the process and elimination of subjective errors.

Keywords: CNC lathe, machining of plastics, fuzzy logic controller (FLC)
\end{abstract}

V članku avtorji opisujejo analizo, ki je omogočala izboljšanje učinkovitosti mehanske obdelave na računalniško numerično krmiljeni (CNC) stružnici. Preizkuse struženja so izvajali na izbranih vzorcih industrijske plastike, pri čemer so izvedli programiranje na osnovi regulatorja zabrisane logike (FLC) za zahtevane pogoje mehanske obdelave tako, da so dosegli optimalne pogoje režima rezanja. Programiranje je vključevalo tri karakteristične vhodne vrednosti in eno izhodno vrednost medtem ko so eksperimentalni rezultati vključevali generiranje glavne oz. povprečne rezalne sile in temperaturo plastike v coni rezanja med mehansko obdelavo na CNC stružnici. S prilagoditvijo procesa na FLC so dosegli pričakovane rezultate: popolno avtonomijo procesa struženja in odstranitev vseh subjektivnih napak.

Ključne besede: CNC stružnica, mehanska obdelava plastike, regulator zabrisane logike (FLC)

\section{INTRODUCTION}

The problem noticed in recent years is the absence of relevant production data about plastic materials and, generally speaking, non-metals. ${ }^{1-3}$ Thermoplastics (or technical plastics as used in the paper) are very often machined in many production plants worldwide and some parts made of these materials have become irreplaceable in numerous constructions, devices and, on the whole, individually exploited elements. There are many examples that support the above statements: mobile phones, car parts, meat grinders, etc. ${ }^{4,5}$

This paper describes a program for executing an experiment with machining technical plastics on a $\mathrm{CNC}$ lathe to obtain the optimal factors of the cutting regimes. ${ }^{2,6-8}$ The program is based on two characteristic units and the experimental results are based on generating the values of the main cutting resistance of the CNC lathe machining F1 $(\mathrm{N})$ and temperature $T(0$ ${ }^{\circ} \mathrm{C}$ ) in the cutting zone of the proposed tribology system. In order to obtain as precise dimensions of the chips as possible, a numeric machine with a $0.01-\mathrm{mm}$ precision was used.

*Corresponding author's e-mail:

prvulovicslavica@yahoo.com (Slavica Prvulović)
The first part of the experiment was set on the basis of a recognizable method that is widely used in machining, i.e., the determination of relevant empirical input values. The second part comprised the setting of the fuzzy logic controller with the aim of eliminating any personal influence on the cutting-regime factors. The technological cutting-regime factors were determined on the basis of the technical possibilities of the machine itself.

\section{MATERIALS AND METHODS}

\subsection{Machine used to perform the experiment}

The experiment described in the present paper was performed using an EMCO F5 CNC lathe with the following characteristics (Table 1):

Table 1: Technical characteristics of the machine

\begin{tabular}{|l|c|c|}
\hline \multicolumn{1}{|c|}{ Name } & $\begin{array}{c}\text { Measurement } \\
\text { unit }\end{array}$ & Value \\
\hline Electric-motor drive power & watt & 440 \\
\hline Tool path along the X axis & $\mathrm{mm}$ & 150 \\
\hline Tool path along the Z axis & $\mathrm{mm}$ & 300 \\
\hline Machine precision & $\mathrm{mm}$ & 0.01 \\
\hline Feed speed & $\mathrm{mm} / \mathrm{min}$ & $5-400$ \\
\hline 6 Spindle speed & $\mathrm{rev} / \mathrm{min}$ & $50-3000$ \\
\hline Interface connection & $\mathrm{RS} \mathrm{232}$ & \\
\hline
\end{tabular}


P. MOŠORINSKI et al.: DETERMINATION OF THE OPTIMAL CUTTING PARAMETERS FOR MACHINING ...

Table 2: Experiment plan

\begin{tabular}{|c|c|c|c|c|c|c|c|c|c|}
\hline & \multicolumn{9}{|c|}{ Measurements } \\
\hline & 0 & 1 & 2 & 3 & 4 & 5 & 6 & 2 \\
\hline$a$ & $(\mathrm{~mm})$ & 1 & 1 & 1 & 1 & 2 & 2 & 2 \\
\hline$v$ & $(\mathrm{~mm} / \mathrm{min})$ & 80 & 80 & 300 & 300 & 80 & 80 & 300 & 300 \\
\hline$f=v / n$ & $(\mathrm{~mm} / \mathrm{rev})$ & 0.133 & 0.067 & 0.500 & 0.250 & 0.133 & 0.067 & 0.500 & 0.250 \\
\hline$n$ & $(\mathrm{rev} / \mathrm{min})$ & 600 & 1200 & 600 & 1200 & 600 & 1200 & 600 & 1200 \\
\hline$\omega$ & $(\mathrm{rev} / \mathrm{s})$ & 62.8 & 126 & 62.8 & 126 & 62.8 & 126 & 62.8 & 126 \\
\hline
\end{tabular}

\subsection{Workpiece}

Figure 1 shows a workpiece made of a technical plastic with dimensions of $\phi 40 \mathrm{~mm} \times 300 \mathrm{~mm}$. The workpiece holder includes the chuck and the tailstock center so its motion is rotary.

\subsection{Cutting force}

If we consider the general oblique cutting, the resulting cutting force consists of three components normal to each other: ${ }^{1,6}$

$F_{1}$ - the main cutting force

$F_{2}$ - the thrust force

$F_{3}-$ the feed force

The most important is the main cutting force, $F_{1}$, and the other two are in relation to it $\left(F_{1}: F_{2}: F_{3}=5: 2: 1\right)$. For this reason, a special attention is given to the methods of measurement and calculation of $F_{1}$. The references offer several methods for experimental measurements of the main cutting force as well as several analytical methods for the calculation of its value. In this paper, we use the calculation method for the experimental measurement and an analytical method for the calculation of this force used also by numerous other authors and presented with the following Equation (1):

$$
F_{1}=C_{k_{1}} \times a^{x_{1}} \times f^{y_{1}}[\mathrm{~N}]
$$

Where:

$a[\mathrm{~mm}]$ - the depth of cut

$f[\mathrm{~mm} / \mathrm{rev}]$ - the feed

$C_{\mathrm{k} 1}, x_{1}, y_{1}-$ the coefficients that depend on the type of the machining material

$\boldsymbol{C}_{\mathrm{k} 1}$ - the specific cutting resistance for $a=1[\mathrm{~mm}]$ and $f=1[\mathrm{~mm} / \mathrm{rev}]$, i.e., $A=1 \mathrm{~mm}^{2}$, where $A$ - the cross-section of the chip. ${ }^{6}$

The values of these constants in the machining of thermoplastics, in this case PTFE (polytetrafluorethylene), are determined according to reference. ${ }^{9}$

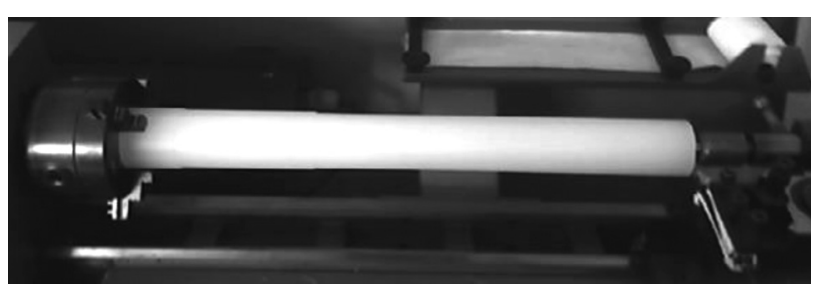

Figure 1: Workpiece

\section{RESULTS AND DISCUSSION}

According to Table 2, parameter $\omega$ [rev/s] $(\omega=$ $\pi n / 30)$ is the angular velocity derived on the basis of parameter $n$. Parameter $f$ (feed) is defined on the lathe in $\mathrm{mm} / \mathrm{rev}$ and is based on the feed speed $(v)$ defined by the manufacturer in $\mathrm{mm} / \mathrm{min}$.

According to the same table, there are eight measurements listed in columns $0-7$ based on the combinations of binary values of the adopted logic variables $(a, f, n)$.

\subsection{Mathematical model for determining the main cutting force}

Analytical dependence of the plastic turning regime may be shown with Equation (1), which is further transformed into a new equation by taking the logarithm of the left and right sides:

$$
\ln F_{1}=\ln C_{k 1}+x_{1} \ln a+y_{1} \ln f
$$

The system of linear algebra equations for one combination of the turning regime can be written as:

$$
\begin{aligned}
& \ln F_{1 \text { max }}-\ln C_{k 1}=x_{1} \ln a_{\text {max }}+y_{1} \ln f_{\text {max }} \\
& \ln F_{1 \text { min } x}-\ln C_{k 1}=x_{1} \ln a_{\text {min }}+y_{1} \ln f_{\text {min }}
\end{aligned}
$$

Based on algebraic equation system (3), the matrix can be written and the resulting values are given in Table 3.

$$
\left(\begin{array}{l}
\ln F_{1 \text { max }}-\ln C_{k 1} \\
\ln F_{1 \text { min }}-\ln C_{k 1}
\end{array}\right)=\left(\begin{array}{ll}
\ln a_{\text {max }} & \ln f_{\text {max }} \\
\ln a_{\text {min }} & \ln f_{\text {min }}
\end{array}\right)\left(\begin{array}{l}
x_{1} \\
y_{1}
\end{array}\right)
$$

Table 3: Results of solving the system of equations (3)

\begin{tabular}{|c|c|c|c|c|c|c|c|}
\hline \multirow{2}{*}{} & \multicolumn{7}{|c|}{ Measurements } \\
\cline { 2 - 8 } & 0 & 1 & 2 & 3 & 4 & 5 & 6 \\
\hline$F_{1 \text { max }}$ & 347 & 158 & 1585 & 262 & 122 & 73 & 982 \\
\hline$F_{1 \min }$ & 149 & 9 & 226 & 218 & 17 & 60 & 27 \\
\hline
\end{tabular}

In this case, the seventh measurement was not valid due to technical problems, which occurred during the experiment.

The control of the obtained results was performed using the electrical parameters $(U-$ voltage and $I-$ current), through the mechanical characteristics of the tool $(L-$ free length of the turning tool) and the angular velocity, $\omega(5)$. The installed measuring system directly detects the force of cutting resistance $\left(F_{1}\right)$ and current 
(I), but due to the voltage variation during the experiment, some measurements did not give valid results and the measurement was repeated. Therefore, a control mechanism was introduced using a formula (Equation 5) to confirm the adequacy of the results given in Table 3 .

$$
F_{1}=\frac{U \cdot I}{L \cdot \omega}
$$

Here, the electric voltage is $U=220 \mathrm{~V}$ and the free length of the turning tool, i.e., imagined console is $L=$ $0.02 \mathrm{~m}$. Electric current I was calculated as the product of the values of correction factor $k_{\mathrm{m}}$ and the current measured using the PLC (programmable logic controller) mounted at the input of the measuring system for detecting the main cutting force and the current (Equation 6). The PLC was added to the measurement system to improve the measurement characteristics of the equipment and was designed to detect the two above-mentioned sizes.

$$
I=k_{m} x I_{P L C}[\mathrm{~A}]
$$

Correction factor $k_{\mathrm{m}}$ was obtained as the value of the flow rate read on the ammeter of the numerically controlled machine and the flow rate detected on the PLC.

Table 4 shows the changes in the cutting force due to the influence of electrical components, voltage and current, which could not be influenced during the experiment without installing additional equipment to prevent variations in the power and voltage. The test of the cutting force was performed for seven measurements with two repetitions, as shown in Table 4, and the results were obtained using Equation (5).

Table 4: Results of $F_{1}$ force according to Equation (5)

\begin{tabular}{|c|c|c|c|c|c|c|}
\hline \multicolumn{7}{|c|}{ Measurements } \\
\hline 0 & 1 & 2 & 3 & 4 & 5 & 6 \\
\hline$F_{1}$ & $F_{1}$ & $F_{1}$ & $F_{1}$ & $F_{1}$ & $F_{1}$ & $F_{1}$ \\
\hline 149 & 9 & 226 & 218 & 17 & 60 & 53 \\
\hline 149 & 9 & 1056 & 240 & 17 & 66 & 27 \\
\hline 149 & 111 & 1207 & 240 & 35 & 66 & 478 \\
\hline 298 & 148 & 1358 & 240 & 70 & 66 & 849 \\
\hline 298 & 158 & 1358 & 240 & 70 & 66 & 876 \\
\hline 298 & 148 & 1358 & 240 & 87 & 66 & 796 \\
\hline 347 & 158 & 1283 & 240 & 70 & 66 & 902 \\
\hline 298 & 148 & 1358 & 218 & 70 & 60 & 690 \\
\hline 298 & 148 & 1358 & 240 & 87 & 66 & 796 \\
\hline
\end{tabular}

\subsection{Fuzzy logic controller (FLC), criteria for the selec- tion of inputs}

The input parameters for the fuzzy logic controller are the cutting regime, feed speed $\mathrm{v}(\mathrm{mm} / \mathrm{min})$ and depth of cut $a(\mathrm{~mm})$, determined by the technical characteristics of the machine.

Considering the defined input parameter of the cutting regime, another important parameter was selected, the temperature of the workpiece as a result of a similar experiment performed on a Potisje PA-22 lathe. ${ }^{9}$
The temperature obtained in this experiment was detected on the top of the tool and measured using a temperature sensor going through the tool handle up to the top of the tool cutting edge. The temperature of the workpiece and the chips was measured using a Fluke 561 IC thermometer.

The obtained values were used to define the temperature areas by programming the fuzzy controller (Table 5).

The temperatures of the turning-tool handle (JUS 9 1010 P10) for the experimental measurements (0-7) are shown in Table 5, namely: maximum $T_{\max }$, minimum $T_{\min }$ and mean value $T_{\text {sr. }}$. The temperature of the handle (together with the temperature of the chips) was measured with the said Fluke 561 IC.

The initial temperature of the workpiece was $21.4{ }^{\circ} \mathrm{C}$.

Table 5: Table of temperature ranges for the tool and workpiece

\begin{tabular}{|c|c|c|c|c|c|c|c|c|c|}
\hline \multicolumn{10}{|c|}{ Measurements } \\
\hline \multicolumn{2}{|c|}{} & 0 & 1 & 2 & 3 & 4 & 5 & 6 & 7 \\
\hline$T_{\text {sr }}$ & ${ }^{\circ} \mathrm{C}$ & 23.5 & 32.5 & 24.5 & 28 & 24 & 27.5 & 22 & 34.5 \\
\hline$T_{\max }$ & ${ }^{\circ} \mathrm{C}$ & 25 & 37 & 25 & 30 & 25 & 30 & 23 & 39 \\
\hline$T_{\min }$ & ${ }^{\circ} \mathrm{C}$ & 22 & 28 & 24 & 26 & 23 & 25 & 21 & 30 \\
\hline$T_{\mathrm{o}}$ & ${ }^{\circ} \mathrm{C}$ & 23.8 & 52 & 22.2 & 36 & 25 & 28 & 24.8 & 48 \\
\hline$T_{\mathrm{n}}$ & ${ }^{\circ} \mathrm{C}$ & 22.8 & 26 & 24.8 & 23.3 & 22.2 & 25.8 & 21.8 & 26.4 \\
\hline
\end{tabular}

The table also shows the other two relevant temperatures, namely, $T_{\mathrm{o}}$ - the temperature of the workpiece and $T_{\mathrm{n}}$ - the temperature of the cutting edge on the rake face. The temperature of the workpiece is a primary input parameter and the only input parameter used for the adaptation of the controller based on the previously defined reasons. A graph showing quantified temperature areas is given in Figure 2.

\subsection{Fuzzy-logic-controller adaptation based on Mam- dani rules}

It is a well-known fact that thermoplastics are machined during the process of casting under pressure and after that, they are machined to the final shape (gears, chains and similar machine elements). The casting

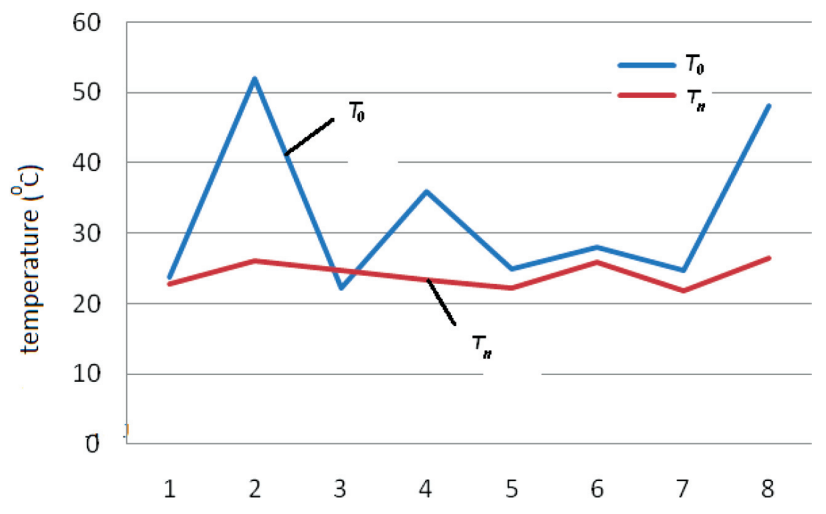

Figure 2: Graph showing the temperature areas 


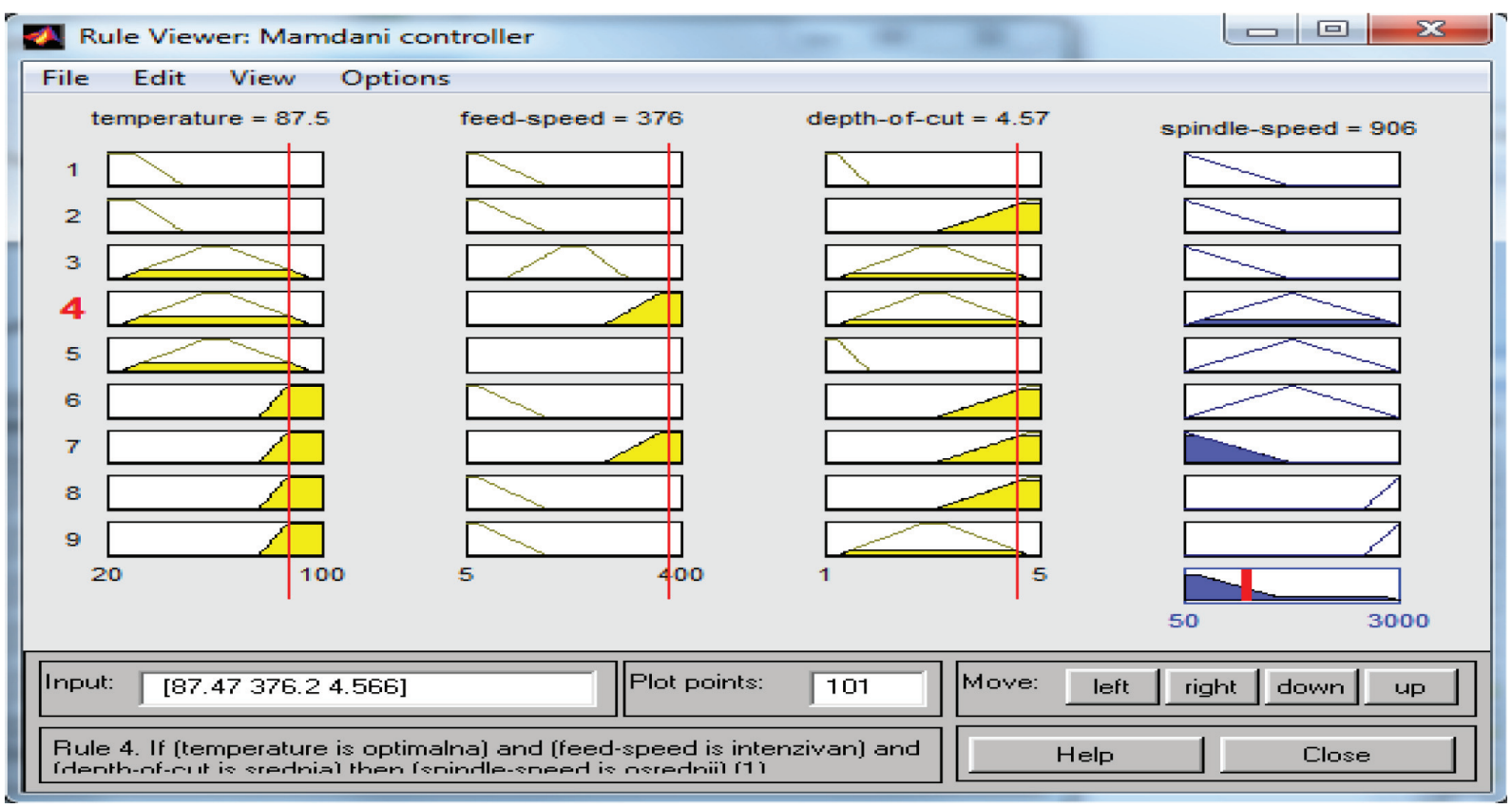

Figure 3: Graphic presentation of the set rules for the controller

temperatures are different and they primarily depend on the chemical structure of the material. Thus, the temperature area of casting is $220^{\circ} \mathrm{C}$ and rises to $440{ }^{\circ} \mathrm{C} \cdot .^{10,11}$ A problem occurs in machining if the temperature exceeds $100{ }^{\circ} \mathrm{C}$. Some plastics lose their mechanical properties at such temperatures and cause serious problems. Plastics then adhere to the tool tip, thus entirely changing the cutting geometry, which considerably affects the quality, accuracy and the required geometric shape of the workpiece. ${ }^{1,9,12-13}$ Even the possibility of machining plastics by cutting them at a higher temperature may be questioned. According to the theory of cutting, the increased number of revolutions gives a better quality of the machined surface. This is the principle of the CNC machines - to obtain as good a quality as possible for as short a time as possible.

The fuzzy-logic-controller adaptation based on the Mamdani rules in this paper is supposed to regulate the number of revolutions of the main CNC machine spindle so that the workpiece temperature can be kept below $100{ }^{\circ} \mathrm{C}$ without using a coolant to avoid the chemical reactions between the coolant and the base material.

The input parameters for the fuzzy controller are the temperature of the machined material, feed speed and depth of cut and the output parameter is the number of revolutions of the main spindle. The acceptable temperature of the workpiece ranges between $\approx 20$ and $100^{\circ} \mathrm{C}$, for the feed speed, it is between $50 \mathrm{~mm} / \mathrm{min}$ and $400 \mathrm{~mm} / \mathrm{min}$ and for the cutting depth, it is between $1 \mathrm{~mm}$ and $2 \mathrm{~mm}$. The controller is set in accordance with 9 rules used to obtain the number of revolutions (Figure 3). The adaptation of the fuzzy controller is based on the Mamdani controller. ${ }^{14-16}$ One of these rules (Rule 4) is completely beyond the limits of the presumed parameters of the cutting regime and shows a sudden jump in the working temperature, which is approximately equal to the maximum predicted temperature for the processing of this material. This shows that the system that regulates the controller should not be disturbed in order for the results of the experiment to be adequate.

\section{CONCLUSIONS}

The primary goal of the experiments was to obtain the main cutting force and temperature of the workpiece by varying the cutting-regime factors such as depth of cut $a(\mathrm{~mm})$, feed $f(\mathrm{~mm} / \mathrm{rev})$ and cutting speed $v(\mathrm{~m} / \mathrm{min})$, i.e., spindle speed $n$ (rev/min). Thus, the applied equipment was optimized with the possibility of scaling some of the electrical values.

The obtained values of the main cutting force also include the values obtained when the cutting tool gets into the workpiece, i.e., they were measured at the moment when the processing did not require the entire length of the blade. At the beginning of the entry of the tool into the cutting zone, there is no elevated temperature of the tool, gluing chips onto the tool blade and, consequently, there are no changes in the geometry of the cutting tool and the characteristic rotation of long chips around the tip of the cutter blade. At this point of observation, the value of the main cutting force is very low and further tests are required to detect and analyze the resistance forces at the start of the processing operation and the conditions, under which it is increased. This means that the increase in the main cutting force and the measured operating temperatures are influenced by other relevant factors that are not covered by this 
experiment, nor can they be detected by the applied controller.

The experiment shows that even the variations of the current parameters can negatively affect the results obtained and that it is necessary to provide constant power during the experiment.

The adjustment of the phase logic controller to the limits of the predicted experiment, based on the technical characteristics of the machine, shows that acceptable results can be obtained within the limits provided. Any disruption of the work (setting a parameter beyond the predetermined limits) can disrupt the expected experimental results, as shown with experimental measurement 4.

All this is a small contribution to improving the production processes in order to increase their efficiency. The experiment can be applied to other cutting technologies such as drilling, milling and grinding, and it is also applicable in production conditions, thus improving production processes by introducing a fuzzy logic controller and other systems within artificial intelligence. ${ }^{1,16-18}$

\section{REFERENCES}

${ }^{1}$ A. Ljevar, M. Rancic, Processing of plastics cutting and surface roughness, Materials from Conference Proceedings, XV Jupiter, Cavtat, Croatia, 1989, 101-105

${ }^{2}$ F. J. Shiou, C. C. A. Chen, W. T. Li, Automated surface finishing of plastic injection mold steel with spherical grinding and ball burnishing processes, International Journal of Advanced Manufacturing Technology, 28 (2006) 1-2, 61-66, doi:10.1007/s00170004-2328-8

${ }^{3}$ R. Karania, D. Kazmer, Low volume plastics manufacturing strategies, American Society of Mechanical Engineers, Design Engineering Division, 118 A (2005) 1, 265-274, doi:10.1115/ IMECE2005-79713
${ }^{4}$ T. D. Lin, C. L. Alan, advances in materials and processing technologies, XVI Book Series: Advanced Materials Research, 939 (2014), 222-229, doi:10.4028/www.scientific.net/AMR.939

${ }^{5}$ B. Latha, V. S. Senthilkumar, K. Palanikumar, Machining science and technology, Taipei 2011, 172-191

${ }^{6}$ A. Ljevar, M. Rancic, Plastics and its processing by cutting, Materials from Conference Proceedings, XV Jupiter, Cavtat, 1989, $101-105$

${ }^{7}$ N. Zhu, W. He, P. Liu, Study on cutting temperature for wood plastic composite, Materials from $19^{\text {th }}$ International Conference Wood Machining Seminar, Nanjing, 2009, 21-23

${ }^{8}$ H. Vasudevan, N. C. Deshpande, R. R. Rajguru, grey fuzzy multiobjective optimization of process parameters for CNC turning of GFRP/epoxy composites, Materials from 12th Global Congress on Manufacturing and Management (GCMM), Univ. Vellore, India, December 08-10, Tamil Nadu, 2014, 185-192

${ }^{9}$ P. Mosorinski, V. Mulic, M. Rancic, Temperatures in the cutting zone during lathe machining engine seals made of plastic (PTFE), Materials from Conf. Proceedings PIM, Zrenjanin, 2013, 301-307

${ }^{10} \mathrm{http}: / /$ www.ipas-sekulic.co.rs/, 10.12.2018

${ }^{11} \mathrm{https}: / / \mathrm{www}$. politerm.rs/politerm-katalog, 15.10.2018

${ }^{12} \mathrm{C}$. Yeh, F. Chen, A knowledge database for NC machine operating codes, International Journal of Advanced Manufacturing Technology, 30 (2006), 9-10, 836-843, doi:10.1007/s00170-005-0131-9

${ }^{13}$ Z. Bouaziz, J. B. Younes, A. Zghal, A fast and reliable tool for estimates for plastic blowing moulds, International Journal of Advanced Manufacturing Technology, 20 (2002) 7, 545-550, doi:10.1007/s001700200188

${ }^{14}$ M. I. Al-saedi, H. Wu, H. Handroos, Intelligent controller of a flexible hybrid robot machine for ITER assembly and maintenance, Fussion Engineering and Design, 89 (2014), 7-8, 1795-1803, doi:10.1016/j.fusengdes.2014.04.016

${ }^{15}$ V. Brtka, Soft computing, University of Novi Sad, Technical Faculty Mihajlo Pupin, Zrenjanin, 2013, 204-21

${ }^{16}$ J. M. Mendel, General type-2 fuzzy logic systems made simple: A tutorial, IEEE Transactions on Fuzzy Systems, 22 (2014) 5, 1162-1182, doi:10.1109/TFUZZ.2013.2286414

${ }^{17}$ B. Nedic, M. Lazic, Production technologies - machining by cutting, Faculty of Mechanical Engineering, Kragujevac, 2007, 180

${ }^{18}$ L. Filipovic, Manual for the design and preparation of technological processes in metal processing by cutting ZUNS, Belgrade, 1999, 31-33 